\title{
DEVELOPMENT OF STRATEGIC PLAN FOR ACMI COMPANIES IN AVIATION INDUSTRY
}

\author{
Marija VAIČIULIONYTË*, Vladislavas PETRAŠKEVIČIUS \\ Economics Engineering Department, Business Management Faculty, \\ Vilnius Gediminas Technical University, Sauletekio av. 11, LT-10223, Vilnius, Lithuania \\ *E-mail: Marija.vaiciulionyte@vgtu.lt
}

\begin{abstract}
Aviation industry showing significant growth around the World. Different specialization companies making partnerships with each other to make aviation imperia even bigger and more stable. The relation between companies provides not only growth but also stagnation of operations. Nowadays Boeing 737-MAX crashes prove that affected major companies were forced to stop operations, due to lack of aircraft. For that reason, ACMI (Aircraft, crew, maintenance, and insurance) companies provided the full capacity to maintain flight operations. From this perspective, ACMI companies living a golden age. These companies' services are booked by major airlines for many months in front, due to unforeseen aircraft type grounding issues. The situation in almost every industry varies between ups and downs by forcing companies to analyze the future strategy development plan. Based on AHP (Analytic Hierarchy Process) and TOPSIS method, it is preferable to buy neither to lease an ACMI services from a longer period perspective. New aircraft are less cheap regarding maintenance schedules, fuel consumption and after full repayment, it becomes airline property. The purpose of the article is to asses ACMI company strategy development to stay in the aviation business after major airlines re-establish their full operations. The leasing company can not be a direct competitor to airlines, therefore it needs to develop specific services, which can attract customers. ACMI company can provide services as fast as possible in unexpected or emergency situations. Moreover giving the flexibility of leasing and providing extra services, makes the company be attractive and unique.
\end{abstract}

Keywords: aviation, ACMI (Aircaft, crew, maintenance, insurance), buy, lease, strategy, airline, aircraft.

\section{Introduction}

Currently, the aviation sector taking one of the most important position, regarding people, cargo and other transfers. All operations regarding air transfers are made by using an aircraft, which belong to an airline or a person. An airline is created by having a different type of specialization- a model of the company. It can be legacy, low-cost airlines (LCC), private jets, cargo airlines, ACMI (aircraft, crew, maintenance, and insurance) and etc. To start making airline operations, it has to have an aircraft, which is produced by manufacture. Crew, which is recruited by a particular assessment. Maintenance organization which will take care of airline fleet and insurance organization. Without all of these aspects, the airline can not start to make their operations. Leading that, if an airline facing a problem regarding operations, the main aim is to find how to fix or replace it, because then the company will have costly difficulties. Nowadays companies started to work together regardless of country, culture, religion or other aspects, they became more related to each other. This means that if one company will be affected by some accident, other partners can be enforced to feel those changes too. This was felt this year (2019) in the aviation sector after two Boeing 737 MAX crashes. After the second aircraft crash, more and more airlines grounded this model aircraft due to local authorities' orders (Hatch, 2019). This lead to unexpected challenges to many airlines across the world. In reaction, ACMI companies have ramped up its ability to support its current or new clients, by providing their services. The global aircraft ACMI leasing market is currently witnessing steady growth. Increasing demand for air travelers is one of the significant factors to spike up market demand. Results show that demand (measured in revenue passenger kilometers, or RPKs) rose 6.5\% compared to six months before in 2018 (IATA, 2019). Besides, growth in the construction of new airports, and also major airlines that are ready to acquire new planes adds to the significant growth of this market. For this reason, airlines can not make all of their operations alone all around the world. ACMI companies created their flexibility in the company formula to act fast and provide full service in case of an unexpected situation. This specific company leasing services to fulfill demand, while nowadays airlines facing issues in operations. TOPSIS and APH methods providing information, regarding experts' evaluation that to have 
an aircraft as a property is much better than to lease it. Moreover, according to provided data United Airlines in US started to change the oldest fleet in the world to the new one. Legacy company bought new and retained aircraft, which provides that leasing aircraft for a big company doesn't make economic sense. Looking for a short perspective, ACMI company can provide full service in a very short time and start to operate as a lessee provider. For both companies, in case of emergency and unforeseen situations, this partnership could be profitable. The current situation provides one of the biggest manufacturer company in the world-Boeing which will arrange airlines aircraft shortage. The situation will remain the same or become more stable than it was before. For how long this demand will depend on manufacture but aviation industry situation will be full from major airlines' perspective and ACMI companies need to maintain this growth and become more stable in the business by making a new strategic development plan.

\section{Aviation industry partnerships between different specialization companies}

Global aviation has a strong network of partner organizations around the World. This partnership chain connecting many fields as pilot training, aircraft manufacture and maintenance, moreover specialist in aviation finance and pilot recruitment. Air travel is a large and growing industry. It is one of the most global industries: connecting people, cultures, and businesses across continents. Driving force propelling globalization process is the reduced cost of transport and communication, which has increased growth in the operations of products and materials share, and in the development of economic and geographic specialization. It means a process greatly accelerated by the development of commercial jet aircraft and cargo transport. Moreover, Open Skies manifestly had a number of benefits on the efficiency of supply and on the levels of society which could reap from air travel (Button, 2008). Looking to recent estimates by the cross-industry Air Transport Action Group (ATAG), the total economic impact of the global aviation industry is around USD2.7 trillion, some 3.5 percent of the world's gross domestic product (GDP) in 2014. This industry also supports globally around 62.7 million jobs and this number increasing every year (Uniting Aviation, 2018). Air transport is a driver of global trade and e-commerce, allowing globalization production. Most of the numbers wouldn't be so high without aircraft and airlines, which are working together to make aviation sector growth (Cederholm, 2014). It is necessary for all stakeholders and partners to work together to maximize the benefits of air transport, and to support the continuous growth of aviation by making relations between more people, more places, make aviation sector in one big part. Airlines utilize aircraft to supply services, and may form partnerships or alliances for codeshare agreements. Different types of airline providing slightly shifted type of service. Low-cost carrier airline model that is operated with an especially high emphasis on minimizing operating cost and without some extra services for customers, scheduling in lower fares and less comfort. The business-class airline, which aims at the higher class travelers, featuring all business class requirements and amenities. Charter airlines, operating outside regularly scheduled intervals, related with travel agencies, ACMI airlines leasing full operation service, which includes aircraft, crew, maintenance, and insurances. These all companies at a certain point start to make partnerships to work together when they can improve operations in their specialization. But not the only different types of airlines making good deals by working together, they are also related to other model companies in all aviation industry. For example, a manufacturing company, such as Boeing, is concentrated to spread aircraft all around the world. Boeing itself is stated in the United States but has customers and employees globally. It includes around 150 countries from where they have customers, employees, and operations in 65 countries. The company has manufacturing, service and technology partnerships with companies and governments worldwide (Boeing, 2007). Making contracts with more than 20,000 diverse suppliers and partners, which includes airlines, private customers (see Figure 1).

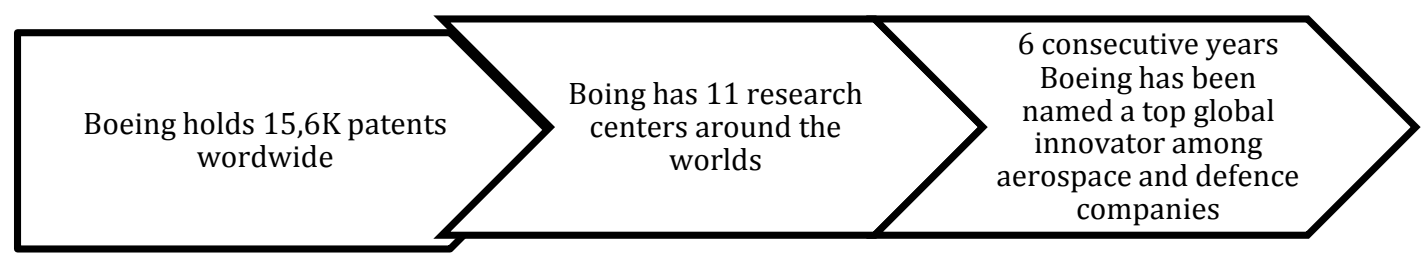

Figure 1. Boeing achievements Worldwide (compiled by the authors on the basis of Boeing, 2019)

No matter what aircraft manufacture is established in the United States many airlines from different countries around the world, ordering aircraft made by Boeing. For example such as Icelandair, Jetstar, LOT, Norwegian Air Shuttle, TUI Group and more have a partnership with the same major manufacture company. This provides that globalization and communication between different countries made a huge impact in the aviation network. Furthermore, a big legacy company such as Qatar Airways, based in Doha, Qatar, has a fleet of more than 200 aircraft (Beers, 2019). Airline relationship with Boeing was renewed in 2008 and since then there have been many milestones in the partnership. It was the first airline in the Middle East, which started operating with Boeing 787 
and is a launch customer for 777X (Boeing, 2019). Moreover, by looking in Europe, German legacy operator Lufthansa Group continue to order aircraft from Boeing. Swiss airlines have expanded its long-haul fleet by a total of nine new Boeing 777-300EU long-haul aircraft since 2016 (Lufthansa group, 2019). Continues orders from different countries continue business running and expanding. If one major company facing problems of delivering orders, competitors were taking them a place by replacing fleets. After Boeing 737-MAX crash, the manufacturer started to feel crisis due to orders canceling from major partners. For example, Airbus won Air Arabia's jet orders, while Boeing orders were canceled. The current situation leads to nearly $70 \%$ of total orders to be frozzen. In October, the company received ten net aircraft orders, a 58\% reduction from the 24 jet orders in 2018. Total MAX crisis costs have reached $\$ 9.2$ billion for Boeing, while Airbus continuously growing (Bhagat, 2019).

\subsection{Aircraft, crew, maintenance, insurance (ACMI) company structure}

The main article object is ACMI company. It is an acronym that stands for the words: Aircraft, Crew, Maintenance, Insurance. The four parts/services which are being "leased" by an operator from another operator. ACMI is flexible type of company, which helps airlines in urgent situations. Of course, it is also the most expensive and least costs effective form of financing an airline operation. ACMI is a wet lease option, which is more a purchase of a service than an actual lease. The process of ACMI contract is that lessee signs a lease contract for an aircraft or a fleet of aircraft, which are being operated by their current operator, while under the lessees AOC (Air Operator Certificate). For easier understanding, ACMI will provide fully certificated aircraft, with the crew which is ready to fly. An airline which is leasing services should be responsible to sell the tickets and make advertisement for their routes, services, and brand. The announced or new planned destinations should be advertised by an airline marketing department. On the other hand, it is easier, because all other operations, including flight planning, crew rostering, documents and maintenance, will be ensured by ACMI provider (Swoboda, 2016). Starting with the first part of ACMI- aircraft. In ACMI company formula the lessor is responsible to ensure everything that is required for the aircraft to be in the sky. It means all documents about aircraft airworthy and maintenance certificates should be updated and valid. Maintenance check schedule, weighing updates, malfunction fixes are based on lessor responsibility. The second part of the service provider is qualified flight and cabin crew- which is provided together with the contract. The meaning of this part of the services providing lessee the capability to start all operations immediately without search of any crew. Crew members are sufficient, with valid license and medical (Burbaite, 2019) They match all current flight operations regulations which provide all rights to fly. Maintenance- is one of the main part of aircraft operations. To make aircraft fly and to be in the air, it should be always maintained according to Part-145 EASA (European Aviation Safety Agency) approvals. Lessor is responsible for ensuring that particular aircraft maintenance is performed all the time. The company should make agreements with line maintenance providers at the airports, where operator is planning to fly. Insurance- ACMI leases the lessor is responsible to make insurance contract and discover all issues, which includes 3rd part liability insurance for the aircraft as well as the operating crew. In conclusion, by reviewing all advantages of ACMI provider, many benefits could be achieved. ACMI allows the lessor to achieve greater fleet efficiency with lower risk during low seasons, new routes (ACCAviation.com, 2019). Moreover, it could be an emergency plan for airlines with a small fleet and no backup aircraft available. It could be ra eplacement for grounded, not delivered aircraft. Looking at the current situation in the aviation industry, after Boeing 737-MAX groundings, ACMI companies made significant growth (Žiemelis, 2019). ACMI provides the ability to make contract a almost immediately, which is one of the biggest benefits in airline operations. Flights will be not canceled, because leesor gives aircraft, fully maintained, with qualified crew members. This availability gives the company advantage of stay in-network, be competitive and save money. Furthermore, ACMI could be transferred to a holiday charter company model, which focuses on the sale of tickets to some destinations and doesn't run the risk of running an airline. Nowadays, VIP flights becoming more and more attractive. As also air transport playing a huge role in the transport industry, "air taxi" can be a new option for airline service. By including VIP operations in ACMI company structure it can improve stability from a variety of possible services to sell.

\section{Methodology}

The article question is related to strategy development for ACMI companies, whose aim is to find the way and problem how to stay competitive and attractive in the aviation business. This should be done regarding calculations, which show results, that to buy a new aircraft for an airline is better. Calculations are done by using the Analytic Hierarchy Process (APH) and TOPSIS methods. Initially, two experts in the aviation industry share their opininion about four different criteria regarding aircraft leasing and buying. Elements in each level are compared pairwise with respect to their importance with each other and different elements. AHP is an absolute scale in which experts used numbers to express how much one criteria dominates another concerning a common criterion (Bahurmoz, 2006). Analysis of experts evaluation and making calculations based on Analytic Hierarchy Method (AHP) provided useful results. This methodology can be expressed as a very helpful tool for decision making and 
weighting criteria for specific actions that should be taken. Comperative altertanives between criterias of aircraft price, time of delivery, crew salary and qualification training cost. Moreover, fuel consumption per kilometer were compared by ratings. When preferences been formed, the procees goes to the next step of deriving relative weights for various elements. Expert number 1 and number 2 provided their ratings of preferences concerning the criteria of alternatives. The ratings model includes a pairwise comparison of the criteria with respect to the goal. Following that, levels of ratings are given with different weight relation number. Pairwise comparisons among the rating levels of each criteria are then conducted to yield a set of priorities for these levels. Within each criteria, also each alternative is assigned a rating level and the associated scaled weights. To get the final score of an alternative is the sum of the product of the criteria weights times the scaled weights with respect to that criteria, where the sum is taken across all the criterias. Moreover criterias computed as the components of the normalized eigenvector associated with the largest eigenvalue of their comparison matrix (Satty, 1996, 2004). The composite weights of the decision alternatives are then determined by putting the weights throughout the hierarchy. This calculation is done by following a path from the top of the hierarchy to each alternative at the lowest level and multiplying the weights along each mark of the path. Following by classical TOPSIS method, we assume that the rating of alternatives and weights are represented by numerical data, which will leade to solve the problem by a single decision-maker. The first stage is to construct the decision matrixes and determine the weight of the criteria for each k-decision-maker. Following that the normalized decision matrix for each decision-maker can be calculated. Each criteria according to the weight and importance should be determined by the positive ideal and negative ideal solutions for each value maker. The separation between the positive ideal and negative ideal solutions will provide distance closer to the ideal situation based on decision-makers' values. Relative closeness to the positive ideal solution will provide values, which corresponds to the larder the index, the better the evaluation of alternatives. The rank of the preference order should be ranked by the descending order of the value and the closest number to one is the best value, based on TOPSIS method calculation (Roszkowska, 2005).

\section{Data analysis}

Article related topics contained information regarding ACMI company strategy development creation. Data was collected not only about company structure but also about aviation industry development, changes and plans. For that reason regarding airline development main questions were raised- is it better to buy or lease an aircraft for a major airline. Due to fast changes in the aviation industry, companies can not always forecast major effects in their operation structure. That is why companies making partnerships and working together by providing different type of services. One of them could have more benefits than the others but by seeing this issue the company can make a new strategic plan for improvement. During data analysis, two experts in the aviation industry provided their opinion according to raised questions (see Table 2). Based on their experience and knowledge results were found according to comparative definitions and their ratings. Data analysis were based on aircraft question to prove what is better for an airline and does ACMI company need to make a new strategic plan in case of situation reestablishment. Analysis of experts evaluation and making calculations based on Analytic Hierarchy Method (AHP) provided useful results. Article calculations are based on four criteria, which are given to make a decision either to buy an aircraft either to lease it from ACMI company in 10 years' perspective. The first criteria is related to the price of an aircraft in both cases. New Boeing B737-800 price taken from the official producer website (Boeing, 2019) states $\$ 106,1 \mathrm{mln}$. By dividing this price per 10 years, yearly payment is $\$ 10,61 \mathrm{mln}$. Furthermore, after 10 years of repayment, an aircraft will be airline property, which increases company financial stability. On the other hand, leasing the aircraft from ACMI by taking the average price for the same model is around $\$ 3150$ per BH (block hour) (Avibroker, 2019). Calculations were based that an aircraft will be flying $8 \mathrm{~h}$ per day, were made for different periods. From comparing perspective, in 10 years the period price of leasing will state for $\$ 84,6 \mathrm{mln}$. It is more than 8 times higher price than buying an aircraft (see Table 3). The company should pay for leasing services, which will make less revenue for them and will not make any property in longer time data. Moreover, when an airline buys an aircraft, it is no BH limit to fly per day, because no contract was made for an hour or cycle price. An airline can operate it's aircraft as many hours as they can legally plan according to aircraft status, maintenance schedule and crew availability. By making more operation hours per day airlines can growth more rapid regarding costly prices for their sold services (see Table 1).

Table 1. Comparative definitions and their ratings (compiled by the authors)

\begin{tabular}{|l|c|}
\hline \multicolumn{1}{|c|}{ Comparative } & Rating \\
\hline Extremely prefered & 9 \\
\hline Very strongly prefered & 7 \\
\hline Strongly prefered & 5 \\
\hline Moderately prefered & 3 \\
\hline Equally prefered & 1 \\
\hline
\end{tabular}


Table 2. Expert comparisons regarding criterias (compiled by the authors)

\begin{tabular}{|l|}
\hline \multicolumn{1}{|c|}{ Expert 1 } \\
\hline Price is strongly, moderately and strongly preferred to time, crew and fuel consumption \\
\hline Time is moderately and very strongly preferred to crew and fuel consumption \\
\hline Fuel consumption is very strongly preffered to crew \\
\hline Expert 2 \\
\hline Price is Extremely, strongly and extremely preferred to time, crew and fuel consumption \\
\hline Time is moderately and extremely preferred to crew and fuel consumption \\
\hline Fuel consumption is extremely preffered to crew \\
\hline
\end{tabular}

Table 3. B737 price list (compiled by the authors)

\begin{tabular}{|l|l|l|l|l|}
\hline Buy & B737-800 NEW & $\$ 106,1$ mln total price & $\begin{array}{l}\$ 884,2 \mathrm{~K} \text { per month to } \\
\text { pay }\end{array}$ & No BH limit per day \\
\hline Lease & B737-800 (2000-2005) & $\begin{array}{l}\$ 25,2 \mathrm{~K} \text { if operating 8 } \mathrm{h} \text { per } \\
\text { day }\end{array}$ & $\begin{array}{l}\$ 8,46 \mathrm{mln} \text { cost per in } 1 \\
\text { year }\end{array}$ & $\$ 84,6$ mln cost per 10 years \\
\hline
\end{tabular}

Note: Price of leasing or buying and aircraft in different period of time.

The following guidelines are time for delivering an aircraft. This is one of the biggest issues if in an urgent situation or rapid development planning more aircraft are needed as fast as possible. Manufacture organization such as Boeing have too many orders by airlines for the B737 model. By the $1^{\text {st }}$ of January of 2019 results, it has 4,763 aircrafts order backlog (Burridge, 2019). During Air Convention Vilnius 2019 conference, many aviation business representatives met to share the most important aviation industry changes and forecast situation. One participant came from Boeing manufacture to share the current situation after the Boeing 737 MAX fleet grounding. Company representative Drew Magil (Managing Director) shared information about outgoing and future orders. The interesting fact states that delivery time could be around 3 or 4 years from now. So no matter, that an airline can come with big investment to buy straight forward more aircraft, manufacture due to capacity issues can not provide product immediately. For that reason, ACMI companies gained more marks according to delivery time, because aircraft is provided in a very short time after signing a contract. If we assume that an airline will do three trips per day and will carry 145 passengers costly situations based on the US Department of Transportation fixed cost of airfare, one scheduled day can cost for a company around \$150k of revenu (Bilitkach, 2019). For that reason, an airline, which has grounded aircraft should make fast replacing regarding aircraft issue. Of course, looking from a crew perspective, the airline has to pay for their crew, which is not making a profit for the company and it is around \$245k per month per one set (EUROCONTROL, 2009). In ACMI leasing crew operational cost is already included. Looking forward, the last criterion is regarding fuel consumption and price fluctuation. Initially, oil prices used to have a predictable seasonality, but nowadays it is no longer foreseeable. The oil industry has changed due to U.S. oil production, uncertainly over OPEC's clout, fluctuations of the dollar and shifts of demand (Amadeo, 2019). Oil prices providing a major part of airline expenses, that is why profits depend on how these prices changing. The period between 2011 and 2017 gives results that fuel expenses averaged at about 27.6 percent in the global airline (IATA, 2018). Though other factors such as consolidation and cost efficiency play a very important role in the growth of airline profits (Egli, 2018). For that reason, to improve fuel efficiency, aircraft manufacture companies started to re-design aircraft airframe and engines. It has been estimated that fuel demands from aviation will change and grow by $1.9 \%-2.6 \%$ each year until 2025. By making lower emissions of reduced fuel consumption and increased fuel efficiency, industry players can continue to build aviation imperia (Koppula, 2018). Moreover, pollutant gases emitted from air jets flying around the World are doing harm environment with rapid growth. The low environmental impact also became a new requirement for developing aircraft design (Yu, 2014). This is the reason why most airlines ordering a new type of aircraft, to increase fuel savings (see Table 4).

Table 4. Fuel consumption data (compiled by the authors)

\begin{tabular}{|l|c|c|}
\hline \multicolumn{1}{|c|}{ Type } & Year & Consumption \\
\hline Boeing 737-300 & 1984 & $3.49 \mathrm{~kg} / \mathrm{km}$ \\
\hline Boeing 737-800 & 1997 & $3.59 \mathrm{~kg} / \mathrm{km}$ \\
\hline Boeing 737-900ER & 2006 & $3.83 \mathrm{~kg} / \mathrm{km}$ \\
\hline Boeing 737 MAX 8 & 2017 & $3.04 \mathrm{~kg} / \mathrm{km}$ \\
\hline Boeing 737 MAX 9 & 2017 & $3.30 \mathrm{~kg} / \mathrm{km}$ \\
\hline
\end{tabular}

Note: Fuel consumption changes according year of aircraft production and type. 


\section{Conclusions}

The aviation industry has many different specialization companies, which are working and related to each other. Relation of companies providing the different impacts of any situation change. One company can be related more with operations stagnation, the other ones, by providing slightly different services, can improve. The airline industry is highly competitive and capital-intensive. Competition is intense as barriers to entry are low due to the liberalization of market entry and the result of globalization impact. IATA (International Air Transport Association) states that around 1,300 new airlines started operations in the past 40 years, which showing the great value of industry growth (Cederholm, 2014). Furthermore, this situation will not change the hierarchy, where major companies have the biggest value and contribution to the industry. Legacy carriers and low-cost carriers (LCCs) taking all industry operations, by working in a different structure of an airline. Airlines' stability and benefits made them strong enough to expand by rights on airport slots, hence and hubs. New markets have fewer entry barriers, which leed newcomers to develop more flexible services. From this article perspectives, ACMI, aircraft and operating service leasing companies can not be straight competitive for major airlines. Leasing company doesn't have enough strength to over-run all flight operations, due to capacity, fleet size, and service type. Furthermore, results show that in a long term overview, for an airline is better to buy. New aircraft are less cheaper regarding maintenance cost, fuel consumption and after full repayment, it belongs as an airline property. Bigger the fleet of an airline, bigger capital of finances. The purpose of this situation is to develop ACMI companies' strategy plan, to maintain and persist in the aviation industry. One of the most attractive ways is to make the company a more flexible comparing of services, which can be provided for the other companies. ACMI model airline should provide services not only as a packed but also separately. First of all by creating a dry leasing contract, which stands for only aircraft rent without redemption, for a specific period. Based on Aviation Consulting Management (2019) it is a great option for companies planning a long-term project or sustainable development goals in business. The minimum package of documents, requiring for aircraft to be airworthy, a quick review of aircraft for operations and short delivery time can be an advantage for an airline. Lessee company will have an opportunity to maintain its crew, provide them an aircraft and plan operations according to their airline procedures. Money-saving will be increased, due to fewer payments for extra crew, as it is included with a full ACMI contract. Furthermore, the legacy airline has its own maintenance organizations, which are responsible for their fleet efficiency. As an example, Lufthansa Technik which shows strong growth in the whole market, rising by $10 \%$ to an all-time high and slight increase in profit. Moreover, this maintenance organization is responsible for more than 5000 aircraft, which belongs not only to Lufthansa Group partners (Lufthansa Group, 2019). From the other perspective, ACMI companies can be more concentrated on their own growth as a charter service provider. It is the business of renting an entire aircraft as opposed to individual aircraft seats. This service could be used as an air taxi, for VIP or tourism agency organized flights. As an example, KlasJet is a European business aviation company, which is specializing in comprehensive aircraft management solutions, moreover private or corporate charter flights (KlasJet, 2019). The company is not only concentrated to provide flights, but allows aircraft owners to enhance the efficiency of their fleet as well as significantly reduce costs related to maintenance and operations. ACMI provider, could create a package as a business or VIP flight, ordered as an air taxi for the specific price. Looking from tourist agencies perspective, holiday packages and seasonality destinations could be attractive and perspective development strategy. As former Thomas Cook Group company operated in two separate segments: a tour operator and an airline. A legendary airline, established more than 100 years ago, with a a siple scheme of services became a colossal company (Leadbeater, 2019). By taking part of Thomas Cook strategy plan and making contracts with famous and largest travels agencies, ACMI companies can develop one more option of service. For ending and summing all availanle options, ACMI company should take in to account subdivide services and lease them separately, make a VIP - air taxi flight package and start holiday charter operations. Flexibility of service options, will attract more customers to start partnership.

\section{References}

Amadeo, K. (2019). Oil price forecast 2019-2050. https://www.thebalance.com/oil-price-forecast-3306219

Avibroker. (2019). Aircraft for Immediate ACMI/Wet/Dry Lease/Sale. https://www.avibroker.com/leaseavailability.asp

Bahurmoz, A. M. A. (2006). The analytic hierarchy process: A methodology for win-win managemant. JKAU: Econ. \& Adm., 20(1), 4-6. https://www.kau.edu.sa/Files/320/Researches/51580_21715.pdf

Beers, B. (2019). Who are the major airplane manufacturing companies? Investopidia. https://www.investopedia.com/ask/answers/050415/what-companies-are-major-players-airline-supply-business.asp

Bhagat, A. (2019). Boeing may lose another mega order to airbus. https://marketrealist.com/2019/11/boeing-may-loseanother-mega-order-to-airbus/

Bilitkach, V. (2019). Boeing 737 MAX: How much could the grounded fleet cost the company? http://theconversation.com/boeing-737-max-how-much-could-the-grounded-fleet-cost-the-company-114863 
Boeing. (2007). 737 performance summary.

https://web.archive.org/web/20140725005129/http://www.boeing.com/assets/pdf/commercial/startup/pdf/737ng_perf.p df

Boeing. (2019). Global Focus. https://www.boeing.com/global/

Burbaite, R. (2019). Aircraft ACMI leasing market: What you need to know. Aerotime Hub. https://www.aerotime.aero/ruta.burbaite/23949-aircraft-acmi-leasing-market-what-you-need-to-know

Burridge, T. (2019) What do the 737 MAX crashes mean for Boeing? https://www.bbc.com/news/business-47812140

Button, K. (2008). The impacts of globalisation on international air transport activity. School of George Mason University, USA. https://www.oecd.org/greengrowth/greening-transport/41373470.pdf

Cederholm, T. (2014). Low-entry barriers intensify competition in airline industry. https://marketrealist.com/2014/12/lowentry-barriers-intensify-competition-airline-industry/

Egli, D. L. (2018). Airline consolidation in Europe (Bachelor's Thesis), 24-25. https://digitalcollection.zhaw.ch/bitstream/11475/12453/1/Bachelor\%2527s\%2520Thesis_Airline\%2520Consolidation \%2520in\%2520Europe_May\%25202018_EGLI\%2520DAVID.pdf

Hatch, P. (2019). Australie Ground Boeing's 737 MAX in wake of fatal crashes. https://www.smh.com.au/business/companies/australia-grounds-boeing-s-737-max-in-wake-of-fatal-crashes-20190312p513hi.html

IATA. (2018). Passenger demand continues strong growth in may. Pressroom. Press Release No. 41. https://www.iata.org/pressroom/pr/Pages/2018-07-05-01.aspx

IATA. (2019). Air passenger market analysis. IATA economics. https://www.iata.org/publications/economics/Reports/paxmonthly-analysis/passenger-analysis-jan-2019.pdf

Yu, W., Hailian Y., Shuai Z., \& Xiongqing, Y. (2014). Multi-objective optimization of aircraft desighn for emission and cost reductions. Chinese Journal of Aeronoutics, 27(1), 52-58. https://doi.org/10.1016/j.cja.2013.12.008

KlasJet. (2019). News. https://www.klasjet.aero/en/page/news

Koppula, R. (2018) The Top 10 Technologies for improving Aircraft Fuel Efficiency. https://www.prescouter.com/2018/01/technologies-improving-aircraft-fuel-efficiency/

Leadbeater, C. (2019). The history of Thomas Cook, from tours for teetotallers to boozy pachages in Spain. https://www.telegraph.co.uk/travel/tours/history-of-thomas-cook/

Lufthansa Group. (2019). Annual report 2019. https://www.lufthansagroup.com/en/themes/annual-report-2019.html

Roszkowska, E. (2005). Multi-criteria decision making models by applying the TOPSIS method to crisp and interval data, 206-211. http://www.mcdm.ue.katowice.pl/files/papers/mcdm11(6)_11.pdf

Saaty, T. L. (1996). Decision making for leaders. The analytic hierarchy process for decisions in a complex world (1 $1^{\text {st }}$ ed.). RWS Publications.

Saaty, T. L. (2004). Decision making- the Analytic Hierarchy and Network Processes (AHP/ANP). Journal of Systems Science and System Engineering, 13, 1-35. https://doi.org/10.1007/s11518-006-0151-5

Swoboda, M. (2016). What is ACMI leasing? airlinebasics.com

Transport Studies Group University of Westminster London. (2009). Dynamic cost indexing. Innovative cooperative actions of research \& development in EUROCONTROL programme CARE INO III.

https://www.eurocontrol.int/eec/gallery/content/public/documents/projects/CARE/CARE_INO_III/DCI_TDD5-

0_Aircraft_crewing-marginal_delay_costs.pdf

Uniting Aviation. (2018). Aviation benefits: Contributing to global economic properity. https://www.unitingaviation.com/strategic-objective/economic-development/aviation-benefits-for-a-better-future/

Žiemelis, G. (2019). Global ACMI will reach 7.07 Billion by 2025. Vilnius Airport News.

\section{STRATEGINIO PLANO KŪRIMAS “ACMI” İMONĖMS AVIACIJOS PRAMONĖJE}

\section{Marija VAIČIULIONYTĖ, Vladislavas PETRAŠKEVIČIUS}

Santrauka. Aviacijos pramonès augimas stebimas visame pasaulyje. İvairios kompanijos plètoja partnerystes, kad aviacijos sektorius taptų dar didesnis ir stabilesnis. Tokie ryšiai tarp kompanijų lemia ne tik augimą, bet ir veiklos sąstingi. Šiandien „Boeing 737-MAX“ avarijos įrodo, kad nukentejjusios didžiosios įmonès buvo priverstos nutraukti veiklą dèl orlaivių trūkumo. Dèl šios priežasties "ACMI” (liet. orlaiviu, igulos, techninès priežiūros ir draudimo) bendrovès suteikia visas galimybes palaikyti oro skrydžių veiklas. Laikoma, kad "ACMI" ịmonès išgyvena aukso amžių. Dèl nenumatytų orlaivio tipo antžeminių problemų didelès oro linijų kompanijos užsako šių bendrovių paslaugas daugeliui mėnesių i priekị. Kiekvienos pramonès šakos situacija yra skirtinga ir nevisada skatina ịmones analizuoti strateginès pletros planus. Taikant AHP (angl. Analytic Hierarchy Process) ir TOPSIS metodus, nustatyta, jog "ACMI" paslaugas ilgesniu laikotarpiu verta pirkti, o ne nuomoti lizingu. Nauji orlaiviai yra gerokai pigesni, atsižvelgiant $\mathfrak{i}$ techninès priežiūros grafikus, degalų sąnaudas, o visiškai išpirkti, jie tampa avialinijų kompanijų nuosavybe. Straipsnio tikslas - ịvertinti "ACMI" kompanijų strategijos plètojimą, siekiant išlikti aviacijos versle, pagrindinems oro linijų bendrovėms vẻl pradèjus savo veiklą.

Raktažodžiai: aviacija, ACMI (lèktuvas, ịgula, techninè priežiūra, draudimas), pirkimas, nuoma, strategija, oro linija, orlaivis. 